http://ejournal.upi.edu/index.php/jaz - e-mail: jurnal.zonasi@gmail.com dan jurnal_zonasi@ upi.edu doi.org/10.17509/jaz.v2i3.19262

\title{
KAJAN BENTUK, FASAD, DAN RUANG DALAM PADA MASJID CHENG HO PALEMBANG
}

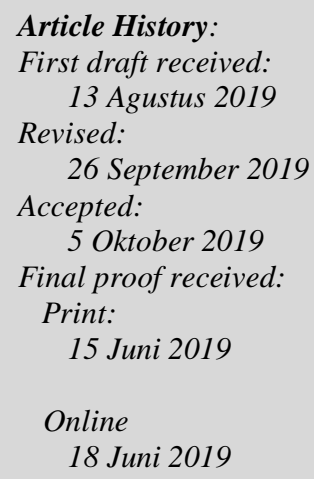

\author{
J.M. Sri Narhadi \\ Universitas Katolik Musi Charitas, Palembang, Indonesia \\ Jalan Bangau No. 60 Palembang \\ Email: narhadi@ukmc.ac.id
}

\begin{abstract}
The architecture of places of worship is one of architecture that is specifically designed to meet human needs in terms of worship. Architecture for a place of worship itself, consisting of church architecture, temples, temples, and mosques. The mosque is a place of worship that is always there in every city in Indonesia, because the majority of Indonesian people are Muslims. Over time, the architecture of the mosque also developed in terms of design by adjusting the culture and environmental conditions. The Cheng Ho Mosque in Palembang is one of the mosques that was established in the city of Palembang with the mosque's unique architectural design and style. The full name of the mosque itself is Al Islam Muhammad Cheng Ho Sriwijaya Mosque. As one of the tourist attractions and also a place of worship of Muslims, Cheng Ho Mosque has attracted the attention of writers to conduct research on mosque design. The different design makes the writer want to research more about the shape, facade and inner space of the Ceng Ho Mosque. Therefore, this research was made under the title Study of Forms, Facades, and Inner Space at the Ceng Ho Mosque in Palembang.
\end{abstract}

Keywords: Form, Façade, Inner Space

\begin{abstract}
Abstrak: Arsitektur tempat ibadah merupakan salah satu arsitektur yang didesain khusus untuk memenuhi kebutuhan manusia dalam hal beribadah. Arsitektur untuk sebuah tempat ibadah sendiri, terdiri dari arsitektur gereja, vihara, klenteng, dan juga masjid. Masjid merupakan salah satu tempat ibadah yang selalu ada di setiap kota di Indonesia, karena mayoritas umat Indonesia adalah muslim. Seiring berjalannya waktu, arsitektur masjid pun berkembang dari segi desain dengan menyesuaikan kebudayaan dan kondisi lingkungan sekitar. Masjid Cheng Ho Palembang merupakan salah satu masjid yang didirikan di Kota Palembang dengan desain dan gaya arsitektur masjid yang cukup unik. Nama lengkap dari masjid ini sendiri adalah Masjid Al Islam Muhammad Cheng Ho Sriwijaya. Sebagai salah satu tempat wisata dan juga tempat ibadah umat muslim, Masjid Cheng Ho telah menarik perhatian penulis untuk melakukan penelitian terhadap desain masjid.. Desain yang berbeda membuat penulis ingin menelliti lebih lanjut mengenai bentuk, fasad dan ruang dalam dari Masjid Ceng Ho. Oleh karena itu, penelitian ini dibuat dengan judul Kajian Bentuk, Fasad, dan Ruang Dalam pada Masjid Ceng Ho Palembang.
\end{abstract}

Kata Kunci: maksimal; empat; kata; kunci.

\section{Pendahuluan}

Arsitektur merupakan sebuah seni dan ilmu yang mempelajari tentang perencanaan dan perancangan sebuah bangunan. Seiring berjalannya waktu, arsitektur terus berkembang menyesuaikan jaman, karena itu telah banyak orang yang tertarik untuk mempelajari bidang arsitektur ini. Pada mulanya, arsitektur sendiri tumbuh dan berkembang karena kebutuhan manusia akan sebuah wadah yang dapat menampung aktivitas atau kegiatan mereka sehari- hari. 
Dalam dunia arsitektur, Arsitektur terdiri dari berbagai macam dan jenis arsitektur, yakni: arsitektur rumah tinggal, sarana dan prasarana fasilitas umum, serta bangunan publik seperti : mall, hotel, gedung serbaguna, sampai tempat ibadah. Arsitektur tempat ibadah merupakan salah satu arsitektur yang didesain khusus untuk memenuhi kebutuhan manusia dalam hal beribadah.

Arsitektur untuk sebuah tempat ibadah sendiri, terdiri dari arsitektur gereja, vihara, klenteng, dan juga masjid (Hidjaz, 2018). Masjid merupakan salah satu tempat ibadah yang selalu ada di setiap kota di Indonesia, menggingat mayoritas umat Indonesia adalah muslim. Seiring berjalannya waktu, arsitektur masjid pun berkembang dari segi desain dengan menyesuaikan kebudayaan dan kondisi lingkungan sekitar.

Kota Palembang merupakan salah satu kota yang memiliki banyak arsitektur masjid diantaranya: Masjid Agung Palembang, Masjid Cheng Ho Palembang, Masjid Lawang Kidul dan masih banyak lagi. Masjid Cheng Ho Palembang merupakan masjid dengan fasilitas tempat ibadah sekaligus tempat wisata yang sering dikunjungi oleh wisatawan, hal tersebut karena masjid ini memiliki desain unik dan berbeda dari arsitektur masjid lainnya.

Masjid Cheng Ho Palembang merupakan sebuah masjid yang didirikan dengan konsep percampuran beberapa gaya arsitektur. Nama lengkap dari tempat ibadah agama Islam ini adalah Masjid Al Islam Muhammad Cheng Ho Sriwijaya. Pembangunan masjid didominasi oleh warna merah dan hijau, diprakarsai oleh para sesepuh, penasehat, dan juga pengurus PITI (Persatuan Islam Tionghua Indonesia) Sumatera Selatan beserta dengan warga Tionghua Palembang .Masjid Cheng Ho Palembang berlokasi di Perumahan Amin Mulia, Jakabaring. Jalan masuk untuk menuju ke masjid ini berada di seberang gerbang Jakabaring Sport City.

Bila dilihat dari tampak fasad secara langsung, bentuk Masjid ini sedikit berbeda dari masjid- masjid pada umumnya. Terdapat desain berbeda, yakni mulai dari: tampak, bentuk, warna yang digunakan dan lainlain. Pada fasad masjid terlihat jelas perpaduan beberapa arsitektur yang mempengaruhi desain masjid ini, diantaranya Arsitektur Cina, dan Arsitektur Masjid pada umumnya.

Sebagai salah satu tempat wisata dan juga tempat ibadah umat muslim, Masjid Cheng Ho telah menarik perhatian penulis untuk melakukan penelitian terhadap desain masjid.. Desain yang berbeda membuat penulis ingin menelliti lebih lanjut mengenai bentuk, fasad dan ruang dalam pada Masjid Cheng Ho. Bentuk, fasad, dan Ruang dalam tersebut meliputi: ruang shalat pada masjid sebagai bagian terpenting masjid, beserta ruang wudhu dan juga toilet sebagai sarana pendukung ibadah untuk masjid ini. Oleh karena itu, penelitian ini dibuat dengan judul Kajian Bentuk, Fasad, dan Ruang Dalam pada Masjid Cheng Ho Palembang.

\section{Permasalahan}

Bagaimana perkembangan bentuk, fasad, dan ruang dalam yang ada pada Masjid Cheng Ho Palembang?

\section{Metode Penelitian}

Metode penelitian yang digunakan pada penelitian ini meliputi: metode survei (pengamatan langsung) dan analisa, metode wawancara yang dilakukan dengan pihak pengurus masjid, serta metode kepustakaan dengan studi literatur melalui buku dan mengakses internet mengenai semua teori yang berhubungan dengan perumusan masalah yang diambil pada masjid Cheng Ho.

\section{Hasil dan Pembahasan}

\subsection{Kajian Bentuk pada Bangunan Masjid Cheng Ho Palembang}

Masjid Cheng Ho sebagai salah satu masjid yang terdapat di Kota Palembang merupakan bangunan masjid dengan bentuk unik dan berbeda dari arsitektur masjid lainnya. Bentuk pada bangunan masjid ini dapat dilihat dari orientasi maupun wujud dari bangunannya.

\section{Orientasi pada Bangunan Masjid Cheng Ho}

Orientasi bangunan Masjid Cheng Ho Palembang, pada dasarnya memperhatikan kaidah- kaidah khusus dalam menentukan arah orientasi bangunannya. Masjid - Masjid umumnya menjadikan arah kiblat sebagai arah orientasi bangunannya, hal yang sama juga terjadi pada Masjid Cheng Ho Palembang. Pada Masjid Cheng Ho Palembang, terlihat jelas arah orientasi masjid dimana bentuk bangunan masjid Cheng Ho Palembang berorientasi ke arah kiblat yakni sebelah barat. Sementara tampak depan/ muka masjid menghadap kearah timur. Pintu masuk/ main entrance juga terdapat pada tampak timur Masjid Cheng Ho. Namun, pencapaian utama pada masjid ini berada di arah barat masjid yakni jalan masuk utama Perumahan Amin Mulia Jakabaring. Hal ini membuat jemaah Masjid Cheng Ho Palembang masuk ke masjid melalui pintu masuk 
yang berada di arah barat, dimana pada arah barat ini terdapat tampak belakang bangunan dan juga lokasi tempat parkir yang cukup luas. Karena itu, pintu gerbang pada tampak belakang masjid lebih sering dimasuki oleh para jemaah dibandingkan gerbang pada tampak depan masjid.

\section{Wujud Bangunan Masjid Cheng Ho Palembang}

Perubahan massa pada bentuk bangunan Masjid Cheng Ho Palembang. Bentuk massa utama bangunan masjid ini masih terlihat yakni berupa kubus dan balok walau telah mengalami penambahan dan pengurangan bentuk.

Penambahan bentuk balok tegak ini berfungsi untuk penutup tangga yakni transportasi vertikal menuju lantai 2/lantai mezanine yang difungsikan juga sebagai ruang shalat pada masjid ini. selain itu adanya balok tegak memberikan kesan kokoh pada bangunan masjid ini.

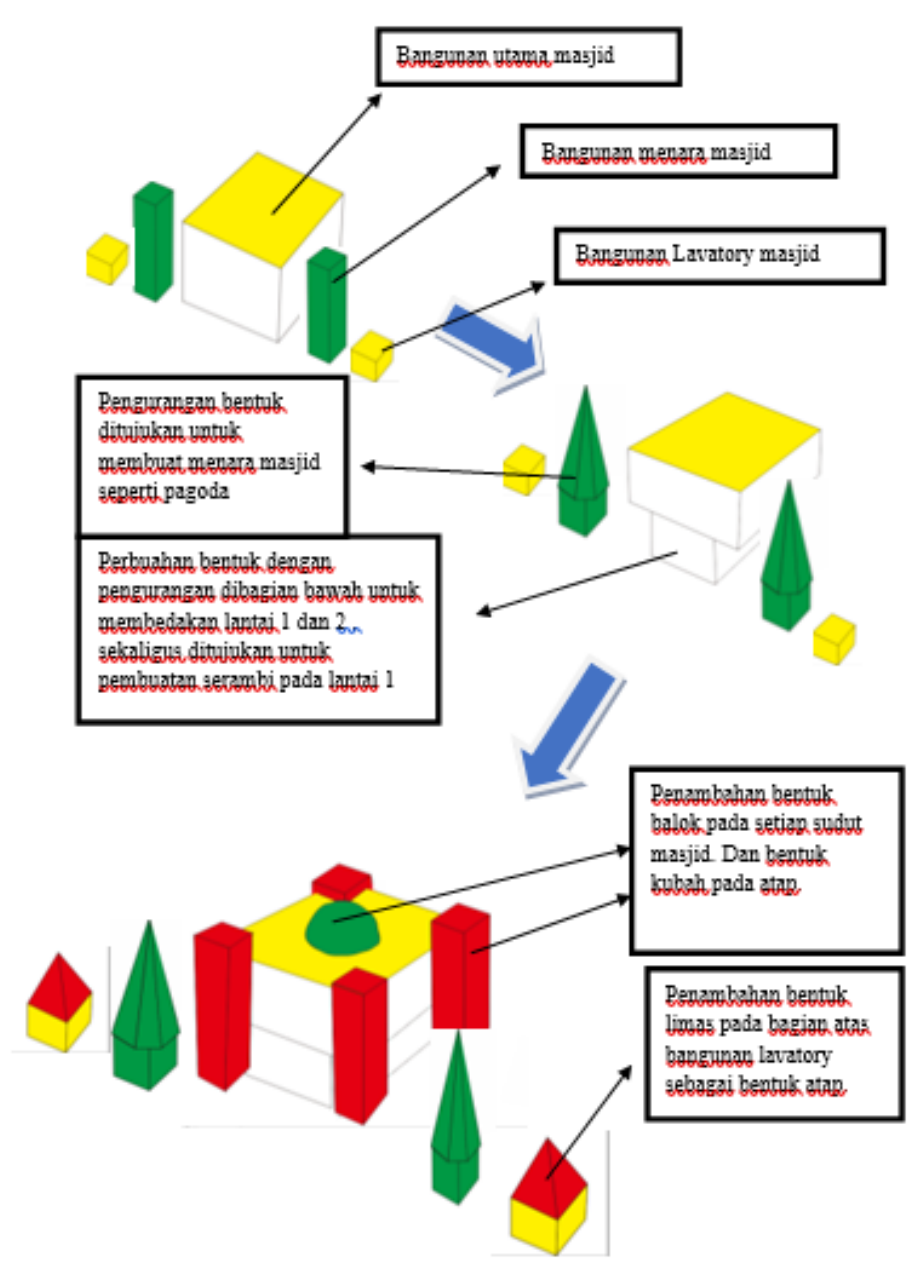

Gambar 1. Perubahan bentuk bangunan Masjid Cheng Ho

Sumber: Dokumen pribadi

\section{Bentuk Denah pada masjid Cheng Ho Palembang}

Bentuk denah pada masjid Cheng Ho Palembang berbentuk persegi. Bentuk persegi ini menyerupai denah masjid pada umumnya. Bentuk persegi membuat sebuah masjid yang memiliki fungsi utama sebagai tempat shalat umat muslim menjadi lebih fungisional. Berdasarkan teori, bentuk persegi akan membuat ruangruang yang terbentuk dapat dimanfaatkan seluruhnya, sedangkan denah yang berbentuk sudut-sudut tertentu (lancip) akan membuat ruangan banyak yang terbuang. Ini berarti, berlebih-lebihan atau akan menyebabkan mubazir. 


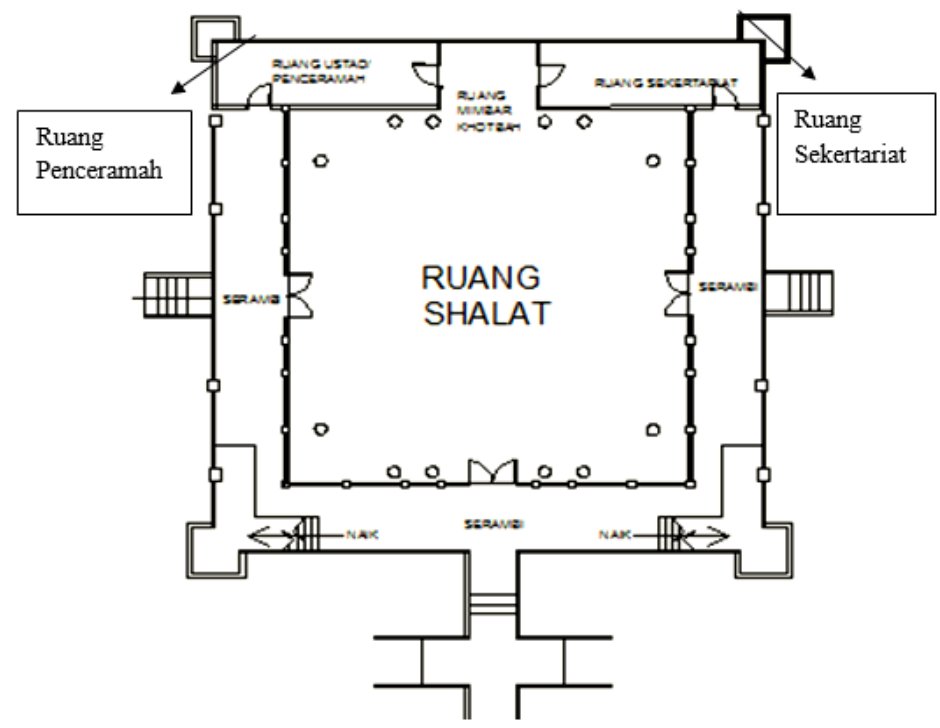

Gambar 2. Denah Lantai 1 Masjid Cheng Ho

Sumber: Dokumen pribadi

\subsection{Kajian Fasad pada Bangunan Masjid Cheng Ho Palembang}

Fasad atau tampak pada bangunan Masjid Cheng Ho Palembang memiliki desain yang cukup unik untuk bangunan sebuah masjid. Kajian fasad bangunan masjid Cheng Ho Palembang ini mencakup kajian tentang fasad pada gerbang masjid, bangunan utama masjid, menara serta lavatory masjid.
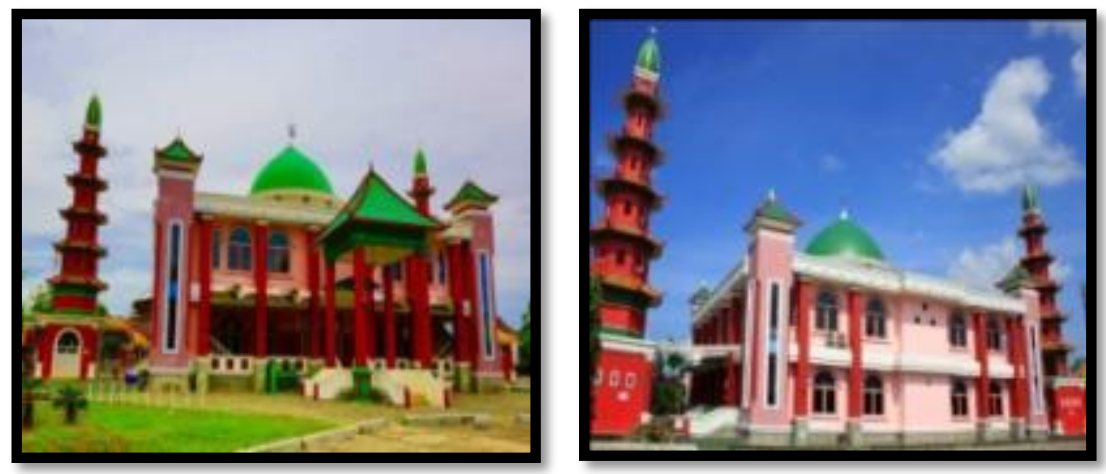

Gambar 3. Fasad depan dan belakang Masjid Chen Ho

Sumber: Dokumen pribadi

\section{Fasad Gerbang pada Bangunan Masjid Cheng Ho Palembang}

Salah satu fasad yang akan terlihat pertama kali pada saat menuju lokasi Masjid Cheng Ho Palembang yakni: gerbang masjid. Gerbang ini memiliki bentuk yang unik dan berbeda dari gerbang bangunan masjid pada umumnya. Berikut adalah gambar fasad gerbang pada masjid.
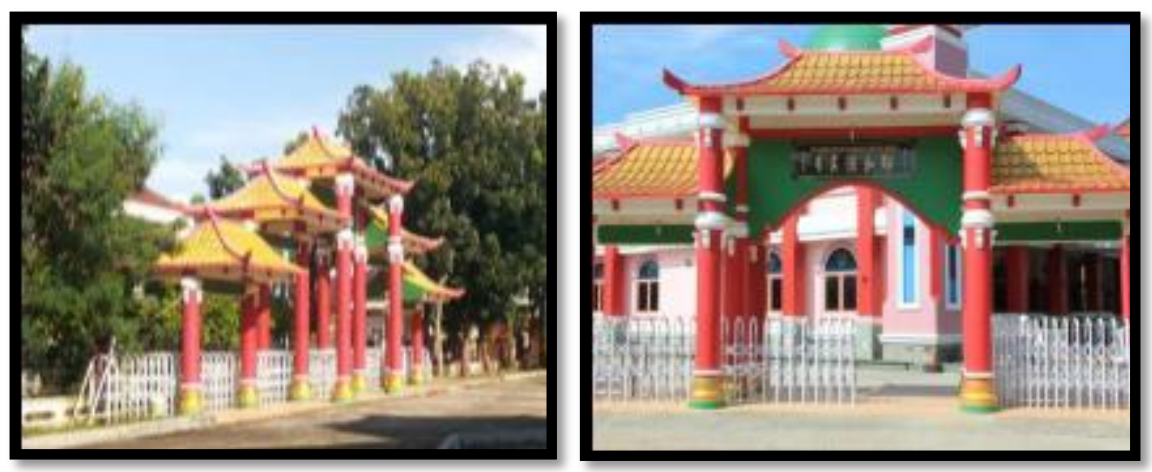

Gambar 4. Fasad gerbang depan dan belakang Masjid Cheng Ho

Sumber: Dokumen pribadi 
Penampilan gerbang pintu masuk pada Masjid Cheng Ho Palembang menyerupai model Arsitektur Tradisional Cina. Model atap masjid yang digunakan adalah atap jenis Wu Tien yakni ciri khas atap tradisional Cina dengan bentuk melengkung pada bagian jurai atap serta ornamen pada bagian atap menyerupai tanduk.
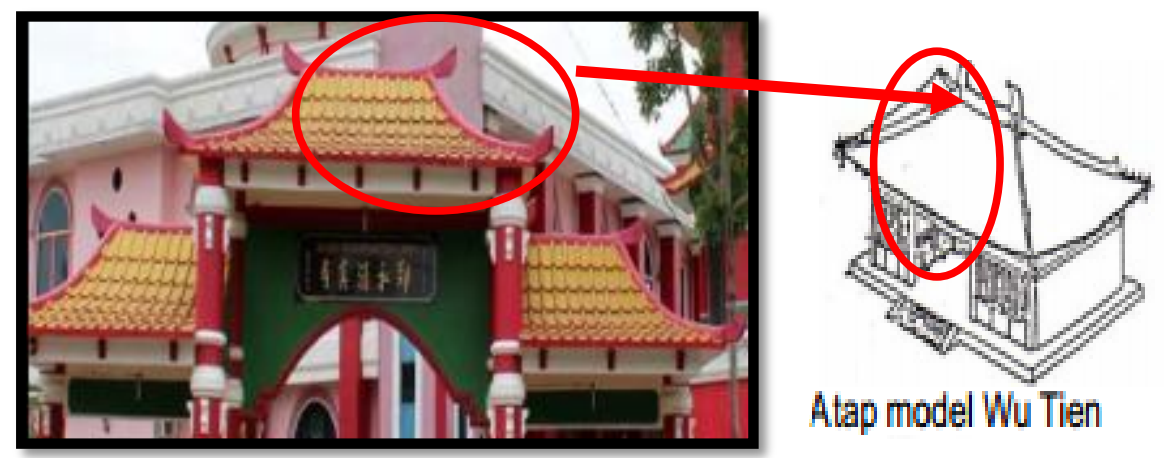

Gambar 5. Atap model Wu Tien

Sumber: Dokumen pribadi

Atap pada gerbang Masjid Cheng Ho ini terdiri dari beberapa tingkatan. Masjid Cheng Ho dengan 2 buah gerbang memiliki jumlah tingkatan atap yang berbeda. Ada yang memuliki 3 tingkatan atap dan ada pula yang 2 tingkatan atap.
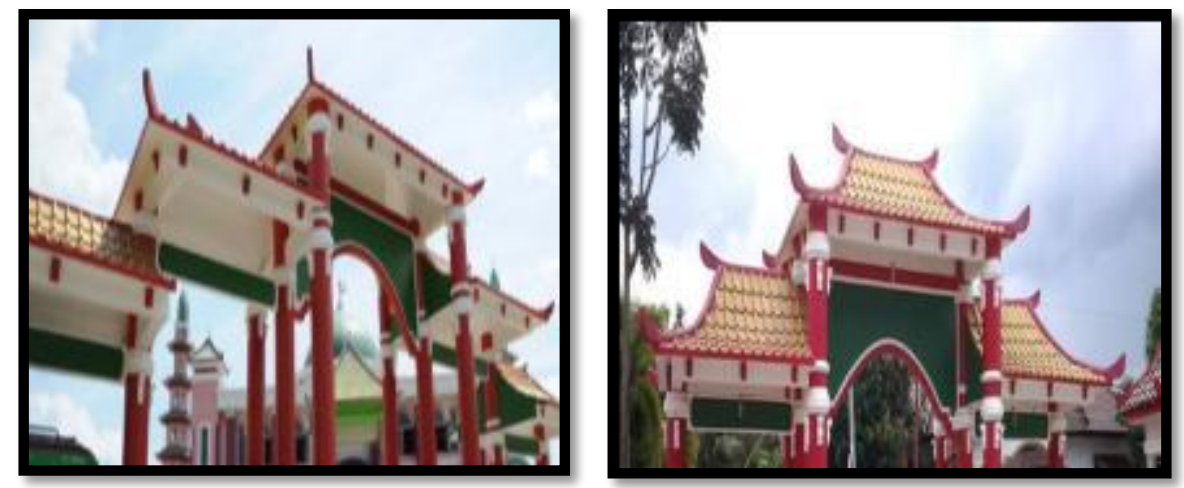

Gambar 6. Atap dengan beberapa tingkatan

Sumber: Dokumen pribadi

Atap dengan beberapa tingkatan juga dimiliki oleh arsitektur gerbang pada Klenteng Cina. Pada Klenteng Cina pada umunya menggunakan atap bertingkat sebagai atap gerbang desain klentengnya. Penggunaan warna pada Gerbang Masjid Cheng Ho dengan dominan warna emas dan merah serta hijau serupa dengan arsitektur Klenteng Cina, Pada plafon gerbang menggunakan warna netral yaitu putih.

Pengunaan warna yang sama terjadi pada arsitektur klenteng Cina yakni dominan warna merah pada atap dan kolom, warna emas pada atap, serta sedikit perpaduan warna hijau pada gerbang.

Penggunaan material serta ornamen pada gerbang Masjid Cheng Ho mulai dari material atap yang menggunakan material genteng, kolom mengunakan material beton bertulang, sedangkan dinding menggunakan material batu bata dan terdapat juga sedikit ornamen pada kolom. Hal tersebut memperlihatkan bahwa fasad pada gerbang Masjid Cheng Ho mengadaptasi bentuk Arsitektur Tradisional Cina terutama arsitektur Klentengnya mulai dari bagian atap, kolom, serta penggunaan warnanya.

\section{Fasad Bangunan Utama, Menara dan Lavatory pada Masjid Cheng Ho Palembang}

Bangunan utama pada Masjid Cheng Ho merupakan bangunan yang digunakan sebagai ruang utama sholat para jemaah muslim, serta juga diisi oleh ruang- ruang lainnya seperti: ruang pengurus sekertariat, ruang mihrab, ruang uztad serta gudang. Pada menara masjid terdapat ruang wudhu dan juga ruang untuk mengumandangkan adzan serta bangunan lavatory yang terletak disamping bangunan menara. Kajian fasad bangunan Masjid Cheng Ho ini dapat dilihat dari beberapa elemen, antara lain: 
A. Proporsi

Masjid Cheng Ho ini terdiri dari 2 lantai dengan ketinggian masing- masing lantai yakni 4 meter, dengan bagian tengah pada lantai 2 masjid dibuat void sehingga pada bagian tengah memiliki tinggi 8m.

B. Irama

Pengulangan kolom ekspos merah sebagai elemen fasad menciptakan sebuah irama pada bentuk fasad masjid Cheng Ho Palembang. Pengaplikasian kolom ini memberikan kesan kokoh dan megah pada masjid Cheng Ho. Irama juga terlihat pada atap bangunan utama masjid. Adanya penggulangan 5 buah atap limas pada masjid berwarna hijau. Namun, pada ba gian main entrance dibuat bentuk atap yang lebih besar, sebagai pembeda untuk bagian main entrance pada bangunan.

Pengulangan 4 buah bentuk balok tegak yang ukurannya lebih besar dari kolom ekspos merah, balok ini berwarna merah muda pada sudut- sudut masjid memberikan kesan kokoh terhadap masjid ini. Bentuk balok dapat dilihat dari fasad depan dan belakang masjid.

\section{Ornamen}

Ornamen yang terdapat pada fasad menara masjid, Menara masjid tidak menggunakan ornamen menara biasanya melainkan menggunakan tipologi bangunan pagoda pada arsitektur Cina yang jumlahnya ada 5 tingkat, menara ini berbentuk segi delapan dengan menggunakan model atap pagoda. Menara ini digunakan untuk mengumandangkan adzan, pada bagian bawah, selain itu pada lantai dasa juga digunakan sebagai tempat wudhu jemaah dengan bentuk denah segi empat. Kedua menara Masjid Cheng Ho Palembang memiliki 5 tingkat yang melambangkan jumlah 5 shalat yang dilakukan dalam sehari. Tinggi menara mencapai 17 meter, angka tersebut merupakan simbol dari jumlah rakaat yang perlu dikerjakan oleh setiap muslim dalam sehari.

Ornamen yang terdapat pada bagian kolom masjid berupa Profil berwarna merah muda menghiasi kolom ekspos yang terlihat pada fasad bangunan masjid. Ornamen pada pintu masuk Lavatory dan ruang wudhu berupa pet melengkung dan bentuk kolom bulat dengan profil berwarna putih. Ornamen lain terdapat juga pada pet masjid berbentuk melengkung dengan bahan seng dan kerangka besi dengan hiasan bunga dari besi.

\section{Warna}

Secara keseluruhan tampak/ fasad bangunan, Masjid Cheng Ho Palembang ini didominasi oleh warna merah mulai dari warna kolom ekspos, warna dinding 2 menara masjid, warna bangunan lavatory masjid, serta penggunaan warna merah muda pada dinding utama bangunan masjid. Penggunaan warna hijau juga nampak pada fasad bangunan yakni pada: bagian Atap tradisional bangunan dan atap kubah serta pada elemen dekorasi dindng maupun kolom kubah yang juga terdapat pada arsitektur masjid pada umunya. Serta penggunaan warna putih pada elemen dekorasi pada pet dan ukiran kolom pada masjid.

Pada menara masjid terlihat penggunaan warna merah dan hijau pada dinding menara dan warna kuning pada atap segi delapan. Penggunaan warna putih pada ornamentasi fasad ruang wudhu mulai dari ornamentasi pintu masuk ,kolom, lubang ventilasi dan pet.

\section{E. Komponen Fasad}

Komponen pada fasad bangunan merupakan bagian- bagian yang akan membentuk wajah dari sebuah bangunan. Komponen dari fasad tersebut antara lain : pintu, jendela, dinding dan juga atap.

\section{Pintu Masuk pada Masjid Cheng Ho}

Terdapat 3 buah pintu masuk pada masjid yakni terletak pada tampak depan, tampak samping kanan dan tampak samping kiri masjid. Pintu pada tampak depan masjid ini berwana hijau dengan tinggi $2 \mathrm{~m}$ dengan 2 daun pintu selebar $2 \mathrm{~m}$ bermotif kotak- kotak berlubang pada bagian atas yang juga berguna untuk sirkulasi udara dalam ruangan. Pintu ini disertai dengan bukaan disampingnya berupa jendela kaca patri. Penampilan pintu pada tampak depan bangunan menjadi semakin megah dengan penggunaan jendela kaca patri. Pintu ini merupakan pintu utama masjid dan biasanya digunakan para kaum muslimah untuk sholat pada hari- hari biasa.

Selain pintu utama terdapat juga 2 pintu lainnya untuk memasuki ruang ibadah masjid menggingat fungsi masjid yang bisa menampung hingga 600 jemaah maka pintu pada bangunan masjid Cheng Ho ini dibuat lebih dari satu, selain itu pintu ini juga digunakan untuk membedakan jalur masuk antara kaum muslimin dan muslimah sesuai dengan syariat masjid pada umumnya. 2 Pintu lainnya ini terletak pada tampak samping kanan dan samping kiri masjid dimana jalur masuk untuk muslimin dan muslimah dapat dibedakan melalui pintu yang ada. 
Kedua pintu ini memiliki ornamen, warna dan bentuk yang sama. Warna dari pintu ini memiliki desain seperti pintu masuk sebuah klenteng pada arsitektur Cina, yaitu warna merah dengan motif lubang kotak pada bagian atas sebagai sirkulasi udara dan terdapat profil pada bagian bawah pintu. Ornamen pintu terdapat pada bagian atas pintu yang juga digunakan sebagai ventilasi. Ornamen tersebut berupa tulisan arab islam berwarna hijau dan kuning yang menghiasi bagian atas pintu ini. Secara keseluruhan bentuk pintu dan ventilasi atasnya menyerupai jendela masjid pada umumnya dengan permainan bentuk lengkung dibagian atas.

\section{Jendela pada Masjid Cheng Ho}

Pada fasad Masjid Cheng Ho terlihat bentuk jendela melengkung, hanya terdapat perbedaan ornamen pada jendela lantai 1 dan lantai 2 masjid. Pada jendela lantai 2 tidak terlihat ornamen islami sedangkan lantai 1 terdapat ornamen islami berupa tulisan arab yang terlihat jelas. Ornamen tambahan pada bagian atas jendela lantai 1 masjid, berupa tulisan arab menunjukkan nuansa islami pada masjid ini. Penggunaan kusen berwarna merah serta jendela kaca.

Bentuk jendela pada lantai 2 Masjid Cheng Ho Palembang, tidak memiliki ornamen islamic seperti jendela pada lantai 1. Jendela berbentuk persegi dengan bagian atas lengkung. Jendela ini menggunakan kaca dengan penggunaan kusen berwarna merah. Penggunaan kusen berwarna merah pada masjid ini juga mencirikan arsitektur klenteng Cina yang rata- rata memiliki bukaan jendela dengan kusen yang berwarna merah sama halnya dengan pintu masjid, bahkan hampir seluruh bagian bangunan pada klenteng Cina menggunakan warna merah. Penggunaan jendela pada masjid difungsikan sebagai bukaan untuk sirkulasi udara dan juga pencahayaan alami pada siang hari.

\section{Atap pada Masjid Cheng Ho Palembang}

Atap utama yang digunakan pada bangunan Masjid Cheng Ho ini berupa atap kubah berwarna hijau dengan simbol islamic yakni bulan dan bintang diatasnya berupa tulisan arab dari bahan stainless steel. Atap kubah ini merupakan ciri arsitektur masjid pada umunya yang biasanya menggunakan atap kubah tepat diatas ruang shalatnya. Selain menghadirkan kesan megah, keberadaan kubah tersebut juga dapat membuat orang yang beribadah di masjid akan merasa kecil di hadapan kebesaran Tuhan yang menciptakannya.

Atap Arsitektur Cina yakni model atap Tsuan Tsien juga digunakan pada masjid ini, terdapat 5 buah atap, 4 buah berukuran kecil terdapat pada sudut- bangunan sedangkan 1 atap lagi yang ukurannya lebih besar terdapat pada bagian main entrance. Atap model Tsuan Tsien ini ini berwarna hijau dengan jurai melengkung berwarna merah, dihiasi juga dengan ornamen pada bagian jurainya yang memberikan kesan arsitektural Cina.

Atap pada menara dan lavatory bangunan Masjid Cheng Ho Palembang. Atap pada menara berbentuk segi delapan dan pada lavatory berbentuk atap limas menyerupai atap Arsitetkur Cina model Tsuan Tsien

\subsection{Ruang Dalam Masjid Cheng Ho Palembang}

Ruang dalam pada Masjid Cheng Ho Palembang terdiri dari ruang shalat utama lantai 1, ruang shalat pada lantai mezanin, ruang penceramah/ uztad, ruang sekertariat, ruang pengurus masjid dan juga gudang. Pada setiap ruang dalam masjid ini memiliki desain tersendiri mulai dari bagian plafon, lantai, dinding dan komponen lainnya.

\section{Ruang Shalat pada masjid Cheng Ho}

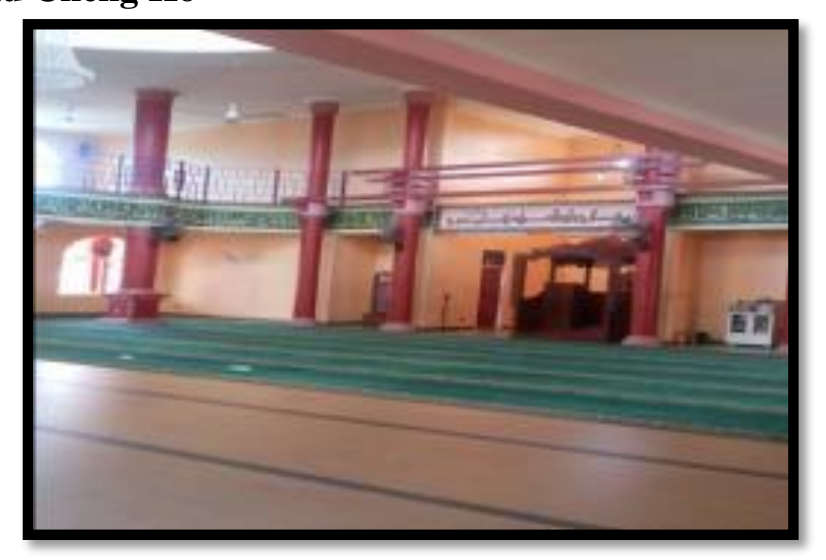

Gambar 7. Ruang Shalat utama

Sumber: Dokumen pribadi 


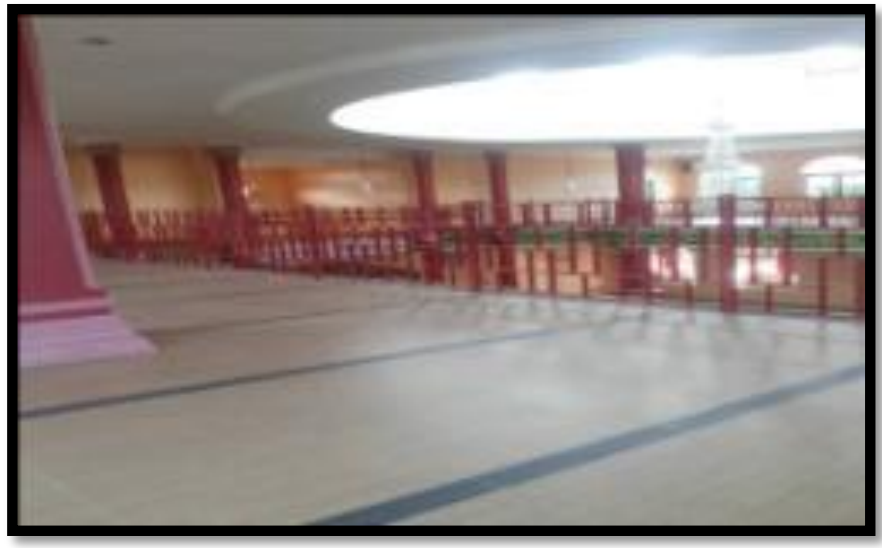

Gambar 8. Ruang Shalat lantai mezanin Sumber: Dokumen pribadi

Ruang dalam untuk ruang shalat masjid terdapat pada lantai 1 dan lantai mezanin. Pada ruang shalat ini terdapat desain tersendiri mulai dari bagian lantai, plafon, dinding, ornamen dan dekorasi, serta perabotan yang disesuaikan dengan keperluan dan konsep yang dibuat pada masjid ini. Berikut beberapa komponen pembentuk ruang dalam pada Masjid Cheng Ho Palembang antara lain:

\section{A. Lantai pada Ruang Shalat Masjid Cheng Ho}

Lantai yang digunakan adalah lantai keramik dengan tekstur batu berwarna coklat dengan perpaduan keramik berwarna hitam berbentuk garis. Desain lantai ini digunakan pada ruang shalat utama lantai 1 masjid dan juga lantai mezanin masjid.

\section{B. Plafon pada Ruang Shalat Masjid Cheng Ho}

Plafon pada masjid menggunakan plafon gipsum dengan warna putih memberikan kesan ruang lebih luas dan besar. Desain plafon lebih modern dan simpel, pada bagian kubah plafon dibuat naik keatas dan dibuat lubang cahaya untuk memasukkan cahaya ke dalam ruang masjid ini juga berguna sebagai pencahayaan alami pada siang hari dan memberikan kesan khyusuk untuk sebuah masjid. Pencahayan buatan berupa lampu kristal yang cukup mewah juga dipasang pada plafon ini. Serta pendingin ruangan berupa kipas angin juga melengkapi bagian plafon ini.

\section{Ornamen dan Dekorasi pada Ruang Shalat Masjid Cheng Ho}

Nuansa islami terasa dari adanya ukiran tulisan arab berwarna emas pada masjid dengan perpaduan warna hijau pada dindingnya.

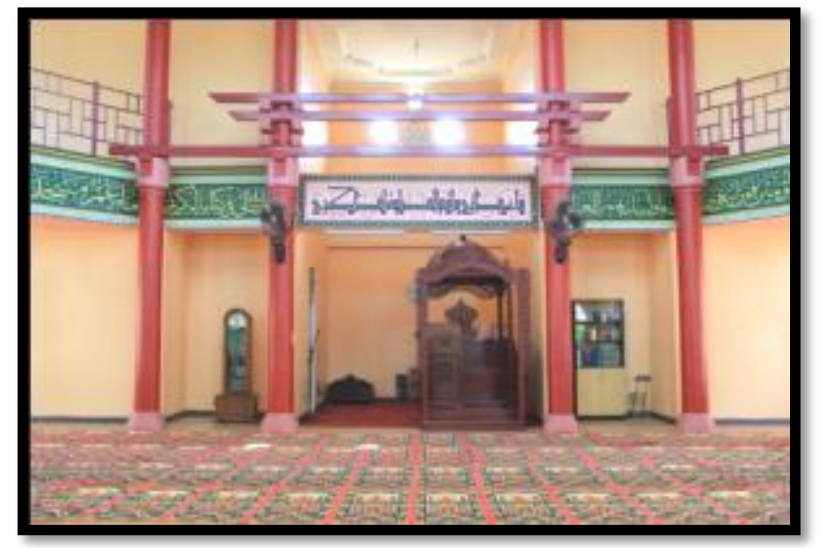

Gambar 9. Tulisan Arab sebagai ornamen hias Sumber: Dokumen pribadi

Penggunaan ornamen sambungan kayu berwarna merah pada bagian atas ruang mimbar. Ornamen ini menghiasi bagian mihrab untuk kotbah pada masjid. 


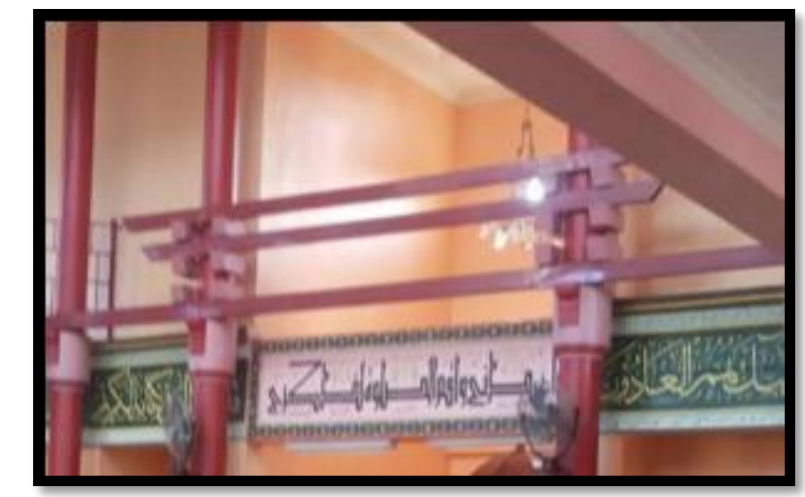

Gambar 10. Ornamen Kayu sebagai ornament hias

Sumber: Dokumen pribadi

Penggunaan ornamen tiang kolom merah ekspos mencirikan arsitektur klenteng Cina yang juga menggunakan kolom merah pada bagian interiornya.
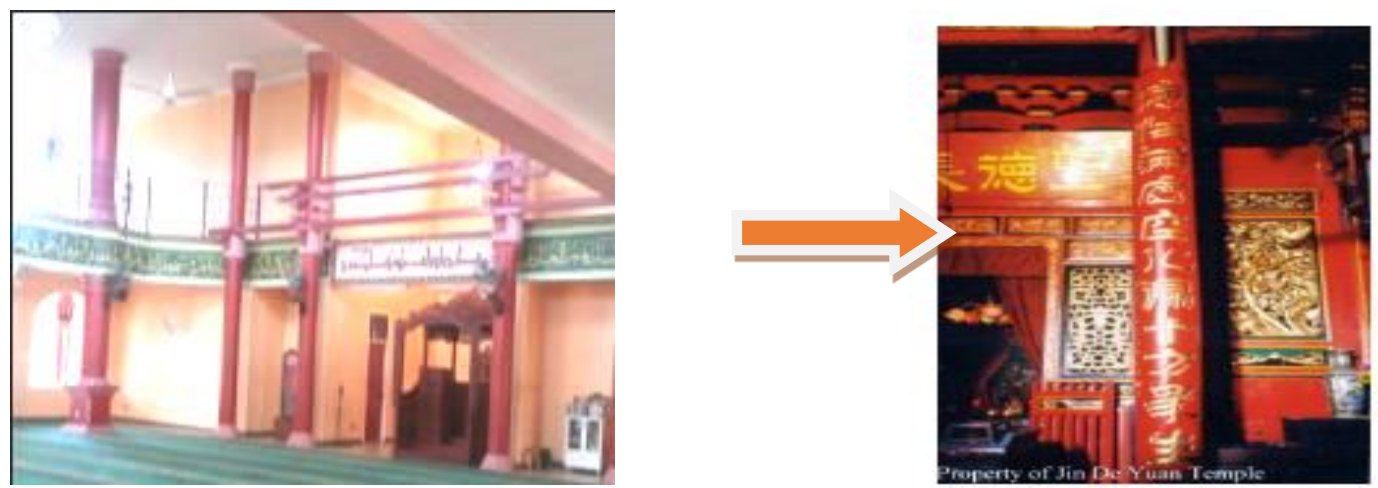

Gambar 11. Ornamen tiang kolom merah

Sumber: Dokumen pribadi

\section{Kesimpulan}

Berdasarkan Kajian Bentuk, Fasad, dan Ruang Dalam pada Masjid Cheng Ho Palembang dapat disimpulkan bahwa :

1. Bentuk pada bangunan Masjid Cheng Ho ini dipengaruhi oleh orientasi arah kiblat yakni sebelah barat sama seperti kaidah masjid pada umumnya. Wujud pada bangunan masjid ini juga merupakan hasil dari perubahan bentuk dengan penambahan dan pengurangan dari bentuk kubus dan juga balok untuk bangunan utama, bangunan menara dan juga lavatory. Selain wujud bangunan, bentuk denah persegi pada masjid Cheng Ho juga mengikuti desain bentuk denah masjid pada umumnya yang menggunakan bentuk persegi dikarenakan lebih fungsional untuk sebuah tempat ibadah dan ruang shalat pada masjid.

2. Fasad pada bangunan Masjid Cheng Ho ini mengandung beberapa elemen fasad diantaranya proporsi masjid yang terdiri dari 2 lantai yang disesuaikan dengan proporsi manusia, Adanya irama/ unsur penggulangan pada fasad mulai dari penggulangan bentuk kolom, atap, dan ukiran- ukiran. Selain itu, pada fasad bangunan Masjid Cheng Ho juga terdapat pengaplikasian desain Arsitektur Tradisional Cina mulai dari kolom merah, penggunaan atap tradisional Cina yaitu atap Wu Tien dan Tsuan Tsien, fasad pada gerbang masjid yang menyerupai gerbang arsitektur klenteng, serta fasad menara masjid dengan bentuk menyerupai arsitektur pagoda pada Aristektur Cina.

3. Ruang Dalam pada Masjid Cheng Ho yakni ruang shalat, ruang pengurus masjid, ruang wudhu serta lavatory memiliki desain dan konsep ruang dalam yang berbeda, mulai dari lantai, plafon, dinding, jendela, perabot dan komponen ruang dalam lainnya sesuai dengan kebutuhan dan fungsi ruang tersebut. Secara keseluruhan ruang dalam pada masjid Cheng. Ho menggunakan plafon gipsum berwarna putih dengan ketinggian disesuaikan dengan kebutuhan ruang, penggunaan jendela lebar untuk ruang shalat, penggunaan lantai keramik, dan perabotan yang disesuaikan dengan fungsi ruangan, serta terdapat juga pengaplikasian ornamen Arsitektur Tradisional Cina pada ruang dalam masjid. 


\section{Referensi}

Achmadi, Abu dan Cholid Narbuko, 2009. Metodologi Penelitian. Jakarta: Bumi Aksara

Ching,Francsis D.K. 2008. Arsitektur Bentuk, Ruang, dan Tatanan. Jakarta: Erlangga.

Hidjaz, T. (2018). Arsitektur Mesjid Sebagai Adaptasi Dan Orientasi Ruang. Jurnal Arsitektur Zonasi, 1(1), $1-15$.

Iskandar, 2008. Metodologi Penelitian Pendidikan dan Sosial. Jakarta: Gaung Persada Press

Khol, David G,1984. Chinese Architecture in The Straits Settlements and Western Malaya. China: Heinemann Asia.

Moleong, Lexy, 2002. Metodologi Penelitian Kualitatif. Bandung: PT. Remaja Rosdakarya

Aiman.2011." Masjid Cheng Ho, Simbol Palembang Multikultur”. http://www.indonesiakaya.com, diakses pada tanggal 16 April 2019, pukul 15.00 WIB.

Mutiah,Mumut. 2011. "Seni Arsitektur Bangunan Masjid". https://www.scribd.com, diakses pada 16 April 2019, pukul 19.00 WIB.

Utami.2013. "Kajian Bentuk dan Fasad Hotel Gino Feruci Bandung". http://download.portalgaruda.org, diakses pada 1 Mei 2019, pukul 15.14 WIB.

Widyarta. 2015."Teori dan Konsep Perancangan Ruang Dalam". https://1219251024iwayanwidyarta.wordpress.com, diakses pada 16 April 2019, pukul 19.15 WIB. 